\title{
NOTES
}

\section{NATIONAL LABOR RELATIONS BOARD: JURISDICTION OVER FOREIGN EMPLOYERS AND EMPLOYEES ${ }^{1}$}

\begin{abstract}
A RECENT assertion of jurisdiction by the National Labor Relations Board in Peninsular EO Occidental Steamship Co., ${ }^{2}$ resulted in the direction of a representation election among ships' crews composed predominantly of non-resident aliens hired by a Liberian corporation to serve aboard two vessels of Liberian registry owned by Liberian companies. The significance of this decision is best appreciated against the background of the recent Supreme Court decision in Benz v. Compania Naviera Hidalgo, S.A., ${ }^{3}$ which held that the Labor Management Relations Act ${ }^{4}$ was not intended by Congress to apply to disputes between a foreign ship and its foreign crew.

The action in the Benz case was for damages resulting from picketing of the S.S. Riviera while the vessel was temporarily in an American port. The suit was instituted in the United States District Court for Oregon which, in accepting jurisdiction, rejected the contention that the Labor Management Relations Act pre-empted the field, holding, rather, that the Act does not extend to a dispute between a foreign ship and its foreign crew. ${ }^{5}$ The Court of Appeals ${ }^{6}$ affirmed in part and reversed in part without reaching the question whether the Labor Management
\end{abstract}

\footnotetext{
${ }^{1}$ The scope of this article does not extend to treatment of the Board's so-called "jurisdictional standards" which represent voluntary limitations on the exercise of its jurisdiction. These standards are based on minimum annual dollar volumes of business below which the Board feels that assertion of jurisdiction over the operations of an employer will not effectuate the policies of the Act. The existence of these self-imposed jurisdictional standards has, in combination with the supremacy clause of the Constitution, created the familiar "no man's land" in the field of labor relations. See Guss v. Utah Labor Relations Board, 353 U.S. x (1957). By contrast, the present discussion is concerned with the Board's legal jurisdiction.

2 x 20 N.L.R.B. No. 147 (1958).

${ }_{353}$ U.S. 138 ( 1957 ). Coincidentally, this case also involved a ship of Liberian registry. However, the ship was owned by a Panamanian corporation and its crew was entirely non-American.

49 STAT. 449, as amended, 61 STAT. 136,29 U.S.C. \$ 15 1 (1952).

353 U.S. at 141 .

- Benz v. Compania Naviera Hidalgo, S.A., 233 F.2d 62 (gth Cir. 1956). Reversal in the Court of Appeals was based on Oregon law to the effect that a judgment could not be entered against the unions as unincorporated associations. Judgments against individual union officials were affirmed.
} 
Relations Act extended to the controversy in question. On certiorari, limited to the issue of the Act's application, the United States Supreme Court affirmed the position of the District Court, stating ${ }^{7}$ that there is nothing in the legislative history of the Act to indicate that Congress intended it should apply to ". . . labor disputes between nationals of other countries operating ships under foreign laws."

\footnotetext{
7353 U.S. at 143 .

${ }^{8}$ This is at least questionable. The Court relied heavily upon a single statement by Representative Hartley: "The bill herewith reported has been formulated as a bill of rights both for American workingmen and for their employers." (Emphasis added by the Court.) H.R. REP. No. 245, 8oth Cong., ist Sess. 4 (1947). From this statement the Court concluded that "what was said inescapably describes the boundaries of the Act as including only the workingmen of our own country and its possessions." 353 U.S. at 144. A fair reading of Hartley's statement, however, could lead to the conclusion that the key phrase is "bill of rights" rather than "American." Certainly the statement is not exclusionary and, in context, has clear reference to $\$ \S 7$ and 8 as well as to $\S \S 2(6)$ and $2(7)$ of the Act. See I Legislativive HistoRY OF THE LaBor Management Relations ACT 295 (1948). Furthermore, this interpretation of congressional intent seems to conflict with the Court's oft-quoted dictum that the term "affecting commerce," under which the Board exercises its jurisdiction, was intended by Congress to exploit the full extent of its power under the commerce clause of the Constitution. Polish National Alliance v. NLRB, 322 U.S. 643 (1944).

The ambiguity of this language becomes apparent when it is applied to facts such as the Board finds in the instant case. When the Court speaks of "nationals of other countries operating ships," the reference may be to the owner or to the officers and crew or to both. Hartley's remark that the Act was for "American workingmen" and the Court's assertion that the Act has application to "only the workingmen of our country and its possessions" also admit of varying interpretations. If this language is construed as limiting the Act's scope to United States citizens only, then the cases in which the Board held that alien status did not remove an employer from the jurisdiction of the Act were in error. The most recent of such cases was decided after Benz. Italia Societa per Azioni di Navigazione, 118 N.L.R.B. III3 (1957). See also Cities Service Oil Co. of Pennsylvania (Marine Division), 87 N.L.R.B. 324 (1949); Seidmon d.b.a. Southwestern Co., 102 N.L.R.B. 1492 (1953) ; Brown Co., I09 N.L.R.B. 173 (1954). A citizenship limitation is, however, inconsistent with the language of the Court, for if the Act covers all "working men ... of our possessons," it, of necessity, covers some non-citizens, e.g., residents of Guam. Furthermore, neither Hartley's "American workingmen" nor the Court's "workingmen of our own country" seems to require any consideration of citizenship; domicile or place of employment seemingly would meet the implication of those statements equally as well as citizenship and would. also be consonant with past Board practice. Under such a construction alien seamen could be considered "workingmen of our country" in that they man ships which regularly sail from a domestic port, carry cargo and passengers principally of United States origin, and are under the continuous and complete operational control of a domestic corporation.

The import of the Court's reference to operation "under foreign laws" is not without ambiguity. In the Beñ case, the ship was not merely registered in Liberia, but also had opened articles of agreement which incorporated conditions prescribed by the British Maritime Board pertaining to wages and hours of employment. What in-
} 
In reaching what only on the surface appears to be an opposite result, the Board in the instant case distinguished the Benz decision on the ground of actual ownership of the vessels, resorting to the familiar tactic of ignoring the existence of a corporate shell operating as an instrumentality of another legal person. ${ }^{9}$ The ownership and chartering arrangement under which the ships in the instant case were operated presents an interesting picture of corporate sham. Prior to August, 1955, both ships sailed under the American flag and were owned and operated by Peninsular and Occidental Steamship Company (hereinafter P\&O), a Connecticut corporation. P\&O decided to transfer the ships to foreign registry in order to avoid a requirement ${ }^{10}$ that vessels of American registry be manned with crews seventy-five per cent of which are American citizens and, thus, to be able to hire foreign crews whose wages in several classifications were about half those being paid American seamen. The ships were transferred to two Liberian corporations, the White Steamship Company and the Blue Steamship Company, both wholly owned by $\mathrm{P} \& \mathrm{O}$ and apparently organized for the sole purpose of

spections, if any, wth respect to safety, sanitation, etc., the vessel underwent in the United States does not appear in the Court's decision. In the present case, the ships had Liberian registry and with that their foreign contracts seemed to end. They were inspected by appropriate agencies of the Government of the United States, and the shipping articles are an old form of United States articles apparently containing nothing required by Liberia which is not also required by the United States. When applied to the facts found by the Board, in the instant case, the problem hinges upon whether, in the Court's view, mere foreign registry constitutes "operating ... under foreign laws."

${ }^{\circ}$ In the Benz case, the Court dealt with a bona fide corporation owned entirely by foreign stockholders and carrying on a substantial shipping business. No member of the crew was an American citizen or resident. The voyage originated in Bremen, Germany, where the crew signed British articles of agreement for a voyage of 2 years or until the ship should return to a European port. The sole American contact was the ship's temporary stop in an American port for the limited purposes of making repairs, taking on a cargo and completing an insurance survey. By contrast, the ships involved in the case before the Board regularly operated between Miami or Tampa, Florida, and Havana, Cuba. The ships' officers were American and almost $1 / 5$ of the unlicensed crew aboard each vessel were either American citizens or residents. Aboard one ship over $4 / 5$ of the crew had signed ships articles in the United States, while aboard the other, I/3 of the crew had signed on in the United States.

${ }^{10} \mathrm{It}$ appears that the Board has accepted this detail of the reason given by the employer for the transfer because it is unimportant to the decision. The statute which the employer asserts to impose this requirement, states only, inter alia, that $75 \%$ of the crew in all departments inust be able to understand any order given by the officers of the ship. 49 STAT. 1935 (1936), as amended, 60 STAT. 1097 (1946), 46 U.S.C. § 672 (a) (1952). It may be that in some ports the effect of either requirement would be practically the same. 
taking title to the two ships. Green Trading Company, a third Liberian corporation organized by $\mathrm{P} \& \mathrm{O}$, then leased both vessels under a bareboat charter, assuming full responsibility for their maintenance, repair and insurance, and further agreeing to pay certain sums each month as rental. On the same day, Green Trading entered into a time sub-charter with $\mathrm{P} \& \mathrm{O}$, under the terms of which $\mathrm{P} \& \mathrm{O}$ was given authority to determine the trading limits of the vessels and was assigned responsibility for maintaiming and operating the ships at its own expense, including such items as repairs and victualing. The remaining function of Green Trading was to employ a full complement of officers and crew for the vessels and to pay wages, including payroll taxes, and other employee benefits. It was provided, however, that $\mathrm{P} \& \mathrm{O}$ would reimburse Green Trading for all these expenses and that $\mathrm{P \& O}$ would have the right to fire for cause any master, officer, or member of the crew. The Connecticut corporation further assumed all responsibilities with respect to insuring the ships and, significantly, the rent which $\mathrm{P} \& \mathrm{O}$ agreed to pay monthly to Green Trading exactly corresponded to the amounts which Green Trading had agreed to pay the Blue and the White Steamship Companies under its charter of the vessels. In further support of its finding that all three of the Liberian corporations were mere instrumentalities of $\mathrm{P} \& \mathrm{O}$, the Board pointed to the fact that all of the directors, officers and operating agents of these corporations were in the employ of $\mathrm{P \& O}$.

The picture of sham hardly could be more complete: All of the Liberian corporations were mere paper shells, each performing a single function for P\&O-that of acting as employer of the crew in the case of Green Trading, and that of holding legal title as a foreign national in the cases of the Blue and White Steamship Companies-while complete beneficial ownership and control of the ships and power to deal directly with the crew as employer remained in the hands of the original owner, a Connecticut corporation owned by American citizens. Thus, the Benz case and the instant decision present situations at opposite poles of corporate reality. Counsel who now would take advantage of the rule enunciated in Benz for the purpose of avoiding application of the Act must explore the middle ground, seeking that degree of corporate reality which will satisfy the Board that the party before it is a true foreign national without its jurisdiction. ${ }^{11}$

\footnotetext{
${ }^{12}$ In at least one case, even before the Benz ruling, the Board declined jurisdiction where there were insufficient American contracts. In Compania Maritima Sansoc Linnitada, S.A., an administrative decision rendered May 1, 1950 (CCH N.L.R.B. Deci-
} 
The interpretation of congressional intent in the Benz decision rests upon a sound policy of refraining from interfering unnecessarily with foreign nationals. Yet even foreign vessels may significantly affect the American labor market where they habitually operate out of American ports, sign on crews in the United States and are able, because of foreign registry, to hire seamen who will work for less than the prevailing wage. The Board's refusal mechanically to apply the Benz ruling in the instant case is, for this reason alone, commendable, and, in fact, the policy underlying the Benz decision is not sacrificed by application of American laws.

Future questions of representation similarly affecting the American labor market in the shipping industry may involve foreign subsidiaries not created primarily for legal maneuvering by a domestic parent, but which carry on a bona fide shipping business extending to United States ports. Though unable to disregard such a subsidiary as a paper shell, the Board might well extend its present policy by asserting jurisdiction under a theory previously employed in a different jurisdictional context: For the purpose of determining whether an employer has sufficient annual volume of business to meet its monetary jurisdictional standards, ${ }^{12}$ the Board has frequently regarded two corporations as a single employer because of common ownership and centralized control of operations, administration, and labor relations policies. ${ }^{13}$ This treatment of two

sions, 1950-195 I, I ro,081, not officially reported), the Board sustained the Regional Director's action dismissing a petition on the grounds that the internal economy of a vessel of foreign registry and ownership was involved. The ship was registered in Panama and belonged to a Panamanian corporation in which the majority of stockholders were Greek nationals, although over $1 / 3$ of the stock was owned by 2 United States citizens. Although it is not clear from the report whether the Board felt that it was powerless to deal with the employer or merely that assertion of jurisdiction would not effectuate the policies of the Act, it was apparently a recognition of the general principle of international law that a ship is part of the territory whose flag it flies. See U.S. v. Flores, 289 U.S. 137, 155-56 (1933). The Board has asserted jurisdiction over a foreign corporation doing business in Puerto Rico. The Royal Bank of Canada (San Juan Branch), 67 N.L.R.B. 403 (1946). See also, Delta Match Corporation, 102 N.L.R.B. 1400 (1953) at n. 2. Furthermore, it has been held that, "although the Board does not have jurisdiction over foreign nationals as such, it does have jurisdiction over unfair labor practices occurring in this country and affecting foreign commerce." Washington-Oregon Shingle Weaver's District Council d.b.a. Sound Shingle Co., 101 N.L.R.B. 1159, 1161 (1952); Moore Dry Dock Co. 92 N.L.R.B. $547,558-560$, n. 77 (1950); Norris Grain Co. v. Nordaas, 232 Minn. 91 , 103-109, 46 N.W.2d 94, 102-104 (1950).

${ }^{12}$ See note I supra.

${ }^{23}$ Brown and Root Caribe, Inc., I 19 N.L.R.B. No. I ro (1957). Cf. Ozark Hardwood Co., IIg N.L.R.B. No. 129 (1957), an unfair labor practice case where 
or more legal entities as a single employer for purposes of asserting jurisdiction under the Act has been approved by the courts. ${ }^{14}$ The mere fact that the employer is an alien corporation should not affect application of the rationale under which closely integrated enterprises are treated as a single employer. Nor should the political considerations involved in applying the laws of one country to persons and property of another nation present any serious difficulty in such a case, for it is well established in international law that foreign nationals submit themselves to the jurisdiction of any nation irto whose territory they voluntarily enter. ${ }^{15}$ The principle of international comity, ${ }^{16}$ allowing matters involving only the internal economy and discipline of a foreign vessel to be governed by the "law of the flag,"117 is not defeated where there is regular and frequent use of American port facilities and the labor of American residents.

An employer subject to the Labor Management Relations Act is bound with obligations ${ }^{18}$ of indefinite duration which often require enforcement. Where a ship is only briefly in American waters, as in the Benz case, ${ }^{19}$ certification of a bargaining representative would seem impractical for lack of opportunity to enforce the bargaining obligation. On the other hand, foreign ownership per se should present no such difficulty where the ship regularly operates out of American ports, and where the employer maintains offices and agents in the United States or may be reached through a closely integrated domestic parent.

a successor employer was held liable for actions of its predecessor on grounds that it was a mere alter ego of the other company.

14 NLRB v. Jones Sausage Co., 42 L.R.R.M. 2467 (CA 4th 1958); cf., Regal Knitwear Co. v. NLRB, 324 U.S. 9 (1945).

${ }^{15}$ It is a recognized rule in the United States that the territory subject to its jurisdiction includes land area under its dominion and control, ports, harbors, bays and other enclosed arms of the sea along its coast and a marginal belt of the sea extending from the coastline outward, a marine league or three nautical miles. Cunard S.S. Co. v. Mellon, 262 U.S. 100 (1923). The Board has followed the general rule of international law that one government will not exercise official (including administrative) functions within the territory of another government. Detroit \& Canada Tunnel Corp., 83 N.L.R.B. 727 (1949).

16 See Benz v. Compania Naviera Hidalgo, S.A., 353 U.S. 138, I42 (1957).

17 Restatement, Conflict of LAWs (1934), followed in Kyriakos v. Goulandris, 151 F.2d 132 (2d Cir. 1945) (Jones Act). Cf., Compania Maritima Sansoc Limitada, S.A., note 11 supra.

${ }^{18} E . g$. , the obligation to bargain collectively in good faith with the representative of a majority of his employees in an appropriate bargaining unit which is imposed by $\S 8$ (a) (5) of the Act.

${ }^{10}$ See note 3 supra. 
Shipowners have often found foreign registry of merchant vessels efficacious in avoiding onerous domestic laws and regulations, thus affording savings in taxes and operating costs. The practice of foreign registry has, for this reason, become an international problem of some magnitude. ${ }^{20}$ The instant decision seems desirable for the additional reasons that it partially nullifies an attempt to avoid application of several American laws, ${ }^{21}$ and is consistent with treatment accorded. similar cases by federal courts in suits under the Jones Act. ${ }^{22}$

\footnotetext{
${ }^{20}$ During 1958, 3 international organizations have discussed the problem: The International Chamber of Shipping at its annual meeting; the United Nations Conference at Geneva, Switzerland, on the Law of the Sea; and the maritime session of the International Labor Conference. The N. Y. Times, Mar. 28, 1958, p. 50:2.

${ }^{21}$ Avoidance of the requirement that $75 \%$ of the crew be United States citizens has already been mentioned. See note to supra. On the basis of a letter submitted with copies of the time sub-charters but without a hearing or other investigation, the Internal Revenue Service ruled as follows:

"We have concluded that the relationship of employer and employee exists, for Federal employment tax purposes, between the Green Trading Company and the officers and crew members. ... In our opinion the controls retained under the subcharter by Green Trading Company over the hiring, selection, rate of pay and discharge of the officers and crew members are sufficient to establish an employment relationship between the company and such individuals. Although the services are to be performed to some extent in accordance with instructions of [P\&O], the Green Trading Company does not relinquish and [P\&O] does not acquire such a right of control and direction over such individuals as would dissolve the employer-employee relationship existing between Green Trading Company and the individuals. The information presented indicates that the Green Trading Company is responsible for the general navigation of the vessels and controls the performance of the officers and crew members." Employer's Exhibit No. 3 in case No. 12-RC-241.

${ }^{22} 4$ I Stat. 1007 (1920), 46 U.S.C. $\$ 688$. (1953). This Act extends to seamen the same rights in actions against employers for damages resulting from personal injuries in connection with their employment as are extended to railway employees under the Federal Employer's Liability Act. It has been held that the "law of the flag" rule, which historically determines conflict of laws problems in this area of international maritime law, is not to be mechanically applied where the nationality of registry and ownership differ. Gerradin v. United Fruit Co., 60 F.2d 927 (2d Cir. 1932), cert. denied, 287 U.S. 642 (1932). Even where American citizens insert a foreign corporation as additional imsulation, immunity from liability may not be achieved if the ultimate ownership is American. Zielinski v. Empresa Hondurena de Vapores, $1_{3}$ F. Supp. 93 (S.D.N.Y. 1953).
} 